\title{
LEGAL CONSEQUENCES OF NON COMPLIANCE WITH BID REQUIREMENTS
}

\author{
Peter Volmink
}

\section{(2014) 1 APPLJ 41}

\begin{abstract}
It is a universally accepted principle of public procurement that bids which do not meet the minimum requirements as stipulated in a bid document are to be regarded as non-responsive and rejected without further consideration. This general principle is subject to certain recognised exceptions. However, the danger always exists that organs of state may apply this rule in a rigid and mechanical fashion or worse, as a means to manipulate the outcome of a tender process. For this reason, the disqualification of bidders on grounds of non-responsiveness has generated a considerable amount of litigation in South Africa. In two recent judgments, the Constitutional Court laid down a framework within which the courts should evaluate the legal effect of bid irregularities. Briefly, the requirement of responsiveness operates in the following manner: a bid only qualifies as a responsive bid if it meets with all requirements as set out in the bid document. Bid requirements usually relate to compliance with regulatory prescripts, bid formalities, or functionality/technical, pricing and empowerment requirements. The standard practice in the public sector is that bids are first evaluated for compliance with responsiveness criteria before being evaluated for compliance with other criteria, such as functionality, pricing or empowerment. Bidders found to be non-responsive are excluded from the bid process regardless of the merits of their bids. Responsiveness thus serves as an important first hurdle for bidders to overcome. But how should administrative bodies approach the issue of non-compliance with bid requirements? How can administrative bodies avoid the twin ills of adopting an overly rigid and mechanical approach on the one hand and disregarding the clear and mandatory prescripts of a tender document on the other? Can an organ of state condone non-compliance with mandatory bid requirements? What are the factors to be considered when deciding whether a bid is responsive or not? These are among the questions which this paper seeks to address.
\end{abstract}




\title{
LEGAL CONSEQUENCES OF NON COMPLIANCE WITH BID REQUIREMENTS
}

\author{
Peter Volmink* \\ BA.LLB, LLM \\ Executive Manager: Governance, Supply Chain, Transnet SOC Ltd \\ Advocate of the High Court of South Africa
}

\section{Introduction}

It is a universally accepted principle of public procurement that bids which do not meet the minimum requirements as stipulated in a bid document are to be regarded as non-responsive and rejected without further consideration. ${ }^{1}$ This general principle is subject to certain recognised exceptions. ${ }^{2}$ However, the danger always exists that organs of state may apply this rule in a rigid and mechanical fashion or worse, as a means to manipulate the outcome of a tender process. As stated by Hoexter:

"[A]n otherwise unimpeachable tender may easily be disqualified at an early stage on a technicality, or organs of state may use defects 'opportunistically' to resile from otherwise unimpeachable contracts". ${ }^{3}$

For this reason, the disqualification of bidders on grounds of non-responsiveness has generated a considerable amount of litigation in South Africa. Typically, legal challenges have arisen in instances where organs of state have disqualified meritorious bidders for relatively minor breaches, or where they have refused to disqualify bidders who failed to comply with mandatory bid requirements.

A decision to exclude a bidder from a tender process is subject to judicial review on the grounds that it qualifies as "administrative action" in terms of the Promotion of Administrative Justice Act of 2000 (South Africa) (PAJA). ${ }^{4}$ Judicial oversight is necessary to ensure that such decisions are taken in a manner which is lawful, reasonable, rational and procedurally fair. ${ }^{5}$ Indeed, our courts have exercised such oversight on numerous occasions, often with vastly divergent outcomes. This is not at all surprising, given the fact that the administration of justice is highly contextual and fact sensitive. Consequently, what may amount to a fair minded exclusion of a bidder on grounds of non-

\footnotetext{
*I would like to thank Prof Phoebe Bolton of Stellenbosch University and my colleague Helen Walsh for their helpful comments on an earlier draft of this article.

${ }^{1}$ Art 43(2)(c) of the UNCITRAL Model Law on Public Procurement A/66/17 of 1 July 2011.

${ }^{2}$ Art 43(1)(b) of the UNCITRAL Model Law allows procuring entities to regard a bid as responsive if it contains minor deviations that do not materially alter or depart from characteristics, terms, conditions and other requirements set out in the bid document or if it contains errors or oversights that can be corrected without touching on the substance of the tender.

${ }^{3}$ Hoexter 2012: 295.

${ }^{4}$ See VDZ Construction (Pty) Ltd v Makana Municipality \& Others [2011] JOL 28061 (ECG) para 11

${ }^{5}$ Logbro Properties CC v Bedderson NO \& Another 2003 (2) SA 460 (SCA) para 5.
} 
responsiveness in one context may not be regarded as fair in a different context. Judicial utterances on the issue of bid responsiveness must therefore be understood within the factual matrix of each decided case.

In two recent judgments, the Constitutional Court laid down a framework within which the courts should evaluate the legal effect of bid irregularities. Extensive reference will be made to these judgments in the course of this paper. To avoid confusion, the judgment delivered by the Supreme Court of Appeal (SCA) in Allpay Consolidated Investment Holdings (Pty) Ltd and Others $v$ Chief Executive Officer of the South African Social Security Agency and Others ${ }^{6}$ is referred to as "AllPay (SCA)", whereas the two judgments delivered by the Constitutional Court are referred to as "AlIPay 1 " (or the "merits judgment"), ${ }^{7}$ and "AllPay 2" (or the "remedy judgment"), ${ }^{8}$ respectively.

Briefly, the requirement of responsiveness operates in the following manner: a bid only qualifies as a responsive bid if it meets with all requirements as set out in the bid document. Bid requirements usually relate to compliance with regulatory prescripts, bid formalities, or functionality/technical, pricing and empowerment requirements. ${ }^{9}$ Bid formalities usually require timeous submission of formal bid documents such as tax clearance certificates, audited financial statements, accreditation with standard setting bodies such as the South African Bureau of Standards (SABS), broad-based black economic empowerment (BBBEE) verification certificates, membership of professional bodies, proof of company registration, certified copies of identification documents and the like. Indeed, public procurement practically bristles with formalities which bidders often overlook at their peril. ${ }^{10}$ Such formalities are usually listed in bid documents as mandatory requirements - in other words they are a sine qua non for further consideration in the evaluation process. ${ }^{11}$ The standard practice in the public sector is that bids are first evaluated for compliance with responsiveness criteria before being evaluated for compliance with other criteria, such as functionality, pricing or empowerment. Bidders found to be non-responsive are excluded from the bid process regardless of the merits of their bids. Responsiveness thus serves as an important first hurdle for bidders to overcome.

But how should administrative bodies approach the issue of non-compliance with bid requirements? How can administrative bodies avoid the twin ills of adopting an overly rigid and mechanical approach on the one hand and disregarding the clear and mandatory prescripts of a tender document on the other? Can an organ of state condone non-compliance with mandatory bid requirements? What are the factors to be considered when deciding whether a bid is responsive or not? These are among the questions which this paper seeks to address. But first, it is necessary to discuss a few general principles.

\section{General principles}

\footnotetext{
${ }^{6} 2013$ (2) SA 501 (SCA).

${ }^{7}$ AllPay Consolidated Investment Holdings (Pty) Ltd and others $v$ Chief Executive Officer of the South African Social Security Agency and Others 2014 (1) BCLR 1 (CC).

${ }^{8}$ AllPay Consolidated Investment Holdings (Pty) Ltd v Chief Executive SASSA (No 2) 2014 (6) BCLR 641 (CC).

${ }^{9}$ The concept of bid responsiveness is used most often in relation to compliance with bid formalities.

${ }^{10}$ Hoexter 2012: 295.

${ }^{11}$ Xantium Trading 42 (Pty) Ltd v South African Diamond and Precious Metals Regulator and another [2013] JOL 30148 (GSJ) para 25.
} 


\section{What is an "acceptable bid"?}

The Preferential Procurement Policy Framework Act of 2000 (South Africa) (PPPFA) employs the term "acceptable bid" instead of "responsive bid". An "acceptable bid" is defined as a bid which in all respects complies with the terms and conditions of the bid document. In Chairperson: Standing Tender Committee and Others v JFE Sapela Electronics (Pty) Ltd and Others, ${ }^{12}$ the SCA ruled that organs of state are only allowed to evaluate bids which may be regarded as "acceptable". Consequently, acceptance of a bid that is not "acceptable" within the definition provided in the PPPFA amounts to an invalid administrative act which will be set aside on review. "13 "Acceptability", like "responsiveness", is thus a threshold requirement for the evaluation and award of bids.

However, the concept of what constitutes an "acceptable bid" extends beyond mere compliance with bid formalities. In JFE Sapela Electronics it was held that the determination of whether a bid ought to be regarded as "acceptable" should not be made solely with regard to compliance with formal bid requirements but must also be determined in light of the requirements of fairness, equity, transparency, competitiveness and cost effectiveness as enshrined in section 217(1) of the Constitution of the Republic of South Africa, 1996 (the Constitution). ${ }^{14}$ In that case, a bidder who had inside knowledge of the fact that certain work outlined in the scope of work put out to tender had already been completed, left the completed work out of reckoning when submitting his price, with the result that his price was significantly cheaper than that of other bidders. The court held that a tender offer which is structured in a manner which undermines the values enshrined in section 217(1) should not be regarded as an "acceptable" offer even though the tender offer technically complies with the requirements of the pricing schedule and all other conditions of tender. ${ }^{15}$

The determination of acceptability thus involves not only a consideration of responsiveness to bid formalities but also compliance with the substantive constitutional requirements outlined in section 217(1). Consequently, a bid which is perfectly responsive to bid formalities may nevertheless fail the test of "acceptability" in terms of the PPPFA.

\section{No single test}

\footnotetext{
122005 (4) SA 487 (SCA).

${ }^{13}$ Para 11. The SCA based its decision on the doctrine of legality which states that organs of state must not exercise any power or perform any function other than those which are conferred upon them by law. See also Dr J S Moroka Municipality v Betram (Pty) Ltd and another 2014 (1) SA 545 (SCA) para 16.

${ }^{14}$ JFE Sapela Electronics, para 14.

${ }^{15}$ In this instance, the successful bidder (Nolitha) had priced very low amounts for certain repair works that were required in the scope of work of the bid, simply because the bidder knew that those works had already been performed by another company and were therefore not required. The other bidders did not know that the repair work was not required and therefore quoted market related prices which were significantly more expensive than the prices offered by Nolitha. The court stated that the mere fact that Nolitha had priced each item did not mean that there had been proper compliance. The fact that Nolitha had priced in the manner in which it did effectively meant that it had omitted from its bid a whole section of work which was itemised in the bill of schedules. Hence the court found that Nolitha had gained an unfair advantage over other bidders who had based their prices on the premise that all the work itemised in the bid document had to be performed.
} 
It would be wonderfully uncomplicated if the test for responsiveness could be reduced to a single formula - such as a simple rule of thumb that bidders who provide all returnable documents by the closing date of the bid are to be regarded as responsive whilst those who failed to provide all such documents are to be regarded as non-responsive. ${ }^{16}$ However, as the discussion below indicates, there is no single or simple test that may be applied to determine the issue of bid responsiveness. This determination calls for a careful weighing up of multiple factors through a process of fair minded reasoning, rather than the adoption of a narrow, rigid or pedantic approach. The consequences of non-compliance may vary depending on the purpose and materiality of the bid requirement in question, the language of the request for proposals (RFP), whether there had been substantial compliance etc. This paper concludes with a proposed matrix of factors to be considered when determining the consequence of non-compliance with bid requirements.

\section{Flexibility versus uniformity}

The case law on bid responsiveness reveals an interesting interplay between two competing principles: the need for flexibility in administrative decision making on the one hand and the requirement for uniformity, predictability and impartial treatment of bidders on the other. These competing principles will be discussed in turn. Firstly, the need for flexibility: administrative law abhors a blind or rigid adherence to a fixed principle. ${ }^{17}$ In administrative law terms this amounts to a "fettering of discretion" ${ }^{18}$ Fettering is undesirable because it deprives the affected person/s of "the benefits of individualised discretionary decision making". ${ }^{19}$

Procurement officials are therefore required to consider the factual nuances of each case to ensure that a proper measure of justice is applied. This principle recognises that the duty to act fairly toward bidders is ever flexible and therefore cannot be reduced to a predetermined formula or be based on a "cookie cutter" mentality. ${ }^{20}$

Secondly, the requirements of uniformity: this principle recognises the importance of insisting upon compliance with formal bid requirements. The Constitutional Court has expressed itself on this topic on various occasions. In Bato Star Fishing (Pty) Ltd v Minister of Environmental Affairs, ${ }^{21}$ the court stated that it is both permissible and desirable for administrative decision makers to apply general criteria in an even handed manner to ensure that the decision making process is fair and consistent. ${ }^{22}$ In Steenkamp NO v Provincial Tender Board, Eastern Cape, ${ }^{23}$ the court stated that

\footnotetext{
${ }^{16}$ Hoexter states: "[I]t would of course be delightfully simple if the failure to comply with mandatory provisions inevitably resulted in invalidity while ignoring directory provisions never had this consequence but, as our courts have recognised many times, the reality is not so clear cut". Hoexter 2012: 292.

${ }^{17}$ Hoexter 2012: 319; Johannesburg Stock Exchange and Another v Witwatersrand Nigel Ltd and Another 1998

(2) SA 308 (A) 321.

18 Hoexter 2012: 318.

19319.

${ }^{20}$ Logbro Properties para 8.

${ }^{21} 2004$ (4) SA 490 (CC).

22 Para 57.

${ }^{23} 2007$ (3) SA 121 (CC).
} 
tender processes require "strict and equal compliance by all competing tenderers on the closing day for submission of tenders". ${ }^{24}$

The Constitutional Court expressed itself most forcibly on the topic in Allpay $11^{25}$ in which it emphasised the role which procedural requirements play in ensuring a fair tender process. The court reasoned that compliance with bid requirements is necessary (a) as a means of ensuring equal treatment of all bidders, (b) to ensure fairness to participants in the bid process (c) as a means of enhancing efficiency and optimality in the outcome and (d) as a safeguard against a process skewed by corruption. ${ }^{26}$ The court thus affirmed that compliance with bid requirements has intrinsic value, a notion which the SCA seemed rather dismissive of. ${ }^{27}$

The Constitutional Court also rejected the notion espoused by the SCA that certain procurement related rules adopted by administrative bodies were purely "internal" matters and as such had no force of law. The SCA drew a distinction between what it referred to as an "internal irregularity" and an "unlawful irregularity" - the former referring to non-compliance with the internal rules of an administrative body, whereas the latter refers to non-compliance with legislative prescripts. The SCA opined that non-compliance with the former would not have any legal consequences, whereas noncompliance with the latter invariably led to invalidity. ${ }^{28}$ The Constitutional Court however took a different view. It held that the procurement framework viewed as a whole constitutes a set of rules which is legally binding on organs of state. That framework consists of constitutional and legislative prescripts, ${ }^{29}$ but also includes the administrative body's own internal rules and circulars, instruction notes issued by National Treasury and the terms of the RFP itself. ${ }^{30}$ All of these prescripts read together "constituted the legally binding and enforceable framework within which tenders had to be submitted, evaluated and awarded". ${ }^{31}$

The significance of this is that organs of state may not disregard internal prescripts at whim. ${ }^{32}$ They are constrained to act within a defined framework of norms and standards which must be applied in an even handed and predictable manner. No concessions may be made to one bidder to which another would not be equally entitled. If Bidder A and Bidder B are similarly placed, the treatment which they receive at the hands of public officials must not be discriminatory, arbitrary or whimsical, but should rather be based on a predetermined set of rules which are consistently applied. Furthermore, invalidity does not depend on whether the instance of non-compliance relates to

\footnotetext{
${ }^{24}$ Para 60.

${ }^{25}$ Allpay 1, para 27.

${ }^{26}$ Para 27.

${ }^{27}$ AllPay (SCA), para 21.

${ }^{28}$ Paras 58 - 59.

${ }^{29}$ Such as s 217 of the Constitution, s 33 (the right to just administrative action), s 195(1) (basic values governing public administration), the PAJA, the Public Finance Management Act of 1999 (South Africa) (PFMA), the PPPFA, the Broad Based Black Economic Empowerment Act of 2003 (South Africa) (BBBEE Act), and relevant regulations promulgated in terms of this legislation.

${ }^{30}$ Allpay 1, paras $31-37$.

${ }^{31}$ Para 38.

${ }^{32}$ Para 40.
} 
"internal" as opposed to legislative requirements, as all these requirements comprise the regulatory universe within which organs of state are required to operate. ${ }^{33}$

The difficulty which arises is this: the greater the level of discretion given to procurement officials, the greater the potential for inconsistent, arbitrary, discriminatory and even fraudulent practices. ${ }^{34}$ Conversely, the greater the degree of rigidity in decision making, the greater the likelihood of predetermined outcomes - with little or no possibility of individualised justice for affected persons. Much of the case law on the subject reflects an ongoing quest to find an appropriate balance between uniform application of the rules and individualised justice.

\section{Procedure versus merit}

It often happens that objections to tender awards are raised by unmeritorious bidders. Administrators, and even courts, are sometimes tempted to reject such complaints out of hand on the grounds that such bidders had no prospect of winning the bid in the first instance. For example, in AllPay (SCA), the court was influenced by the fact that the technical solution offered by AllPay (Pty) Ltd was inferior when compared to that of the winning bidder. However, in the merits judgment the Constitutional Court made it clear that even unmeritorious bidders are allowed to raise a complaint that a procedural requirement was overlooked during the tender process. This is because the requirement of administrative justice focuses on the fairness of the process and not the correctness of the tender award. ${ }^{35}$ The court explained that:

"[T]enderers have a right to a fair process, irrespective of whether they are ultimately awarded the tender [hence] it is vital that the procedure and the merit should be kept strictly apart, since otherwise the merits may be prejudged unfairly". ${ }^{36}$

\section{Inconsequential irregularities}

In AllPay (SCA), the court held that it was not in the public interest to invalidate a tender process because of what it referred to as "inconsequential irregularities". ${ }^{37}$ An inconsequential irregularity is one which if corrected, would still yield the same outcome. ${ }^{38}$ The implication of the SCA's ruling was that the courts should be slow to interfere with a tender award despite the existence of an irregularity, if rectifying the irregularity would not change the competitive position of the bidders or

33 In AllPay 1, para 40, the Constitutional Court explained that it should not be understood to mean that administrators may never depart from the system it had put in place or that deviations will necessarily result in procedural unfairness. Rather, administrators may deviate from their own procedures only when the basis for doing so is reasonable and justifiable and the process of change followed is procedurally fair.

${ }^{34}$ GN 691/1997 Green Paper on Public Sector Reform Procurement Reform in South Africa (April 1997) para 2.3.

${ }^{35}$ AllPay 1, paras $42 \& 45$.

${ }^{36}$ Para 26.

${ }^{37}$ AllPay (SCA), paras 21 \& 96.

${ }^{38}$ In AllPay 2, para 19, the Constitutional Court stated that: "[A]n irregularity is inconsequential when, on a hindsight assessment of the process, the successful bidder would likely still have been successful despite the presence of the irregularity". 
make a difference to the outcome of the tender process. This approach was firmly rejected by the Constitutional Court in the merits judgment. The Constitutional Court explained that the inevitability of the outcome of a tender process should not be taken into account as a factor when considering the validity of the administrative action under review. ${ }^{39}$ Consequently, courts should not shy away from declaring an act invalid simply because the tender outcome would be the same if the defect were to be corrected.

In outlining what it referred to as the "proper" legal approach, the Constitutional Court emphasised the distinction between determining whether a reviewable irregularity had occurred and the selection of an appropriate remedy to address the irregularity - the two issues should not be conflated. The court outlined a three step reasoning process to be followed when dealing with a bid irregularity: Firstly, it ought to be established, factually, whether an irregularity occurred. This would involve a determination as to whether there was any deviation from prescribed tender rules or bid conditions. Secondly, the irregularity must be assessed to determine whether it amounts to a ground of review under the PAJA. This involves taking into account the materiality of the deviation from the stated bid requirements. The degree of non-compliance must be considered in light of the purpose of the provision that was not complied with. The question to be asked at this stage is whether the purpose of the tender requirement was substantively achieved despite the non-compliance. ${ }^{40}$ Thirdly, if the administrative decision is found to be constitutionally invalid, a "just and equitable" remedy must be applied. It is only at this stage that the inevitability of the outcome should be taken into account. The court intimated that it may be inequitable to require a rerun of a flawed tender process if the result would be the same,$^{41}$ thus indicating that not every finding of invalidity would necessarily result in the setting aside of a tender award. An inconsequential irregularity may thus influence the nature of the remedy to be applied, but it should not serve as an obstacle to judicial review.

\section{Vagueness}

"Vagueness" is not specifically mentioned in the PAJA as a ground for review. However, vagueness and uncertainty can be accommodated as a ground for review under section 6(2)(i) of PAJA as administrative action which is "otherwise unconstitutional or unlawful". ${ }^{42}$ The rule against vagueness requires that documents be written with reasonable certainty, not perfect lucidity. ${ }^{43}$ However, tender documents which do not provide sufficiently clear information about bid requirements create confusion and thus fall short of the requirement of fairness. ${ }^{44}$ In GVK Siyazama Building Contractors (Pty) Ltd v Minister of Public Works \& Others, ${ }^{45}$ the High Court overturned a decision to exclude a bidder for non-compliance with formalities because the bid document did not spell out the formal requirements with sufficient clarity.

\footnotetext{
${ }^{39}$ Allpay 1, Para 23.

40 Allpay 2, para 58.

${ }^{41}$ Para 29.

42 AllPay 1, para 87.

${ }^{43}$ Paras $87-92$.

${ }^{44}$ Paras 87 - 92.

45 [2007] JOL 20439 (D).
} 


\section{Different judicial approaches to non-compliance with bid requirements}

Broadly speaking, court rulings on the issue of compliance with bid requirements can be grouped into three categories: those which have adopted a flexible approach, those that have insisted upon strict adherence and those that have adopted a purposive approach.

\section{Flexible approach}

This approach places the emphasis on substance rather than form. It requires that greater weight be placed on those factors which are material to assessing the merits of a bid, as opposed to other factors of peripheral importance. In Millennium Waste Management (Pty) Ltd $v$ Chairperson Tender Board: Limpopo Province and Others, ${ }^{46}$ the SCA stressed that the overarching principles of fairness, equity, transparency, competitiveness and cost effectiveness should be afforded greater weight than concerns regarding formal compliance. In this case, a bidding company was disqualified from a tender process on the grounds that the director had completed but failed to sign a declaration of interest form. Since actual signature of the form was a mandatory tender requirement and since bidders had been forewarned in the tender document that failure to comply with the administrative aspects of the tender would lead to disqualification, the tender board held that non-compliance could not be condoned. The SCA nevertheless overruled the decision of the tender board to disqualify the bidder for the following reasons:

- Significantly, in this instance the applicable regulatory framework afforded the tender committee the necessary discretion to condone non-compliance with tender conditions. ${ }^{47}$

- The court regarded the failure by the bidder to sign the declaration of interest form as an inadvertent and innocent oversight.

- The court held that our law permits condonation of non-compliance with mandatory requirements of a tender if the condonation would promote the public interest and if the condonation is granted by the body in whose benefit the provision was enacted. The court observed that since the bid price of the successful bidder was almost eight times higher than the price offered by the disqualified bidder, condonation would have served the public interest by promoting cost effectiveness and competition among tenderers. ${ }^{48}$

- The court was of the view that the definition of "acceptable tender" in the PPPFA should not be given its wide literal meaning:

"It certainly cannot mean that a tender must comply with conditions which are immaterial, unreasonable or unconstitutional." ${ }^{\text {49 }}$

\footnotetext{
2008 (2) SA 145 (SCA).

${ }^{47}$ Regulation 5(c) of the regulations promulgated in terms of the Limpopo Tender Board Act of 1994 (South Africa) provided that: "[T] he Board may accept any offer notwithstanding the fact that the offer was not made in response to any particular tender invitation, or does not comply with the tender invitation in respect of which the offer has been made". See Regulations in terms of the Limpopo Tender Board Act 2 of 1994 PN 4/1997.

${ }^{48}$ Millennium Waste, para 17.

${ }^{49}$ Para 19.
} 
The materiality of the bid requirement, ${ }^{50}$ the reasonableness of its inclusion and whether it infringes upon constitutional safeguards are thus all relevant factors to consider.

- The court also stated that in determining whether non-compliance rendered the tender unacceptable, regard must be had to the purpose of the declaration of interest form, which was to combat corruption. The court found that this purpose had been fulfilled since the director had declared that the company had no relationship with any of the department's officials. The court stated that what was of paramount importance was that the bidder had provided the information required - the fact that he had failed to sign the document was of lesser importance. ${ }^{51}$ By disqualifying the bidder for not submitting a signed document, the court found that the organ of state had acted unreasonably and in conflict with the PAJA.

The SCA's ruling in Millennium Waste has subsequently been clarified and also partly overruled in its recent decision in Moroka Municipality. The latter case ruled that administrative bodies do not enjoy a blanket discretion to condone non-compliance with mandatory bid requirements in all instances. Rather, they have the power to condone non-compliance with mandatory provisions only when they have been afforded the discretion to do so in the RFP document or some other enabling provision. Further on in this paper it is argued that the approach adopted in Moroka Municipality is not entirely congruent with the purposive approach adopted by the Constitutional Court in AllPay 1.

In Minister of Social development $v$ Phoenix Cash and Carry, ${ }^{52}$ the SCA also highlighted the dangers inherent in adopting an unduly rigid approach to the issue of responsiveness. The court emphasised that a process which places undue emphasis on form at the expense of substance could facilitate corruption by providing an excuse for officials to eliminate bidders based on administrative considerations as opposed to issues of substance, thus defeating the objectives of fairness, transparency, competitiveness and cost effectiveness. ${ }^{53}$ The court called for a consideration of criteria which went to the heart of the tender (ie matters which are essential to the evaluation of the merits of the bid) as opposed to matters of peripheral importance. However, the SCA also made it clear that its ruling should not be interpreted to mean that organs of state are not allowed to prescribe formalities in bid documents, which if not complied with could lead to invalidity. ${ }^{54}$

A number of High Court rulings have followed this flexible approach. Thus for example, the courts have overruled a decision taken by a municipality to disqualify a bidder who failed to provide an original municipal billing clearance certificate as required by the tender document, ${ }^{55}$ have refused an

\footnotetext{
${ }^{50}$ In Tedcor (Pty) Ltd \& Another v Mbombela Local Municipality \& Another [2006] JOL 17762 (T) the Court considered the effect of the failure on the part of the successful bidder to include a copy of a draft agreement which it intended to conclude with the Municipality, as required by the RFP. The Court considered this to be a material requirement as it enabled the Municipality to decide whether it wished to conclude a contract on the terms proposed by the bidder.

${ }^{51}$ Millennium Waste, para 20.

52 [2007] JOL 19529 (SCA).

53 Phoenix Cash \& Carry, para 2.

${ }^{54}$ Para 2.

${ }^{55}$ VDZ Construction (Pty) Ltd v Makana Municipality and Others [2011] JOL 28061 (ECG). In this instance only the first page provided by the bidder was original, the second page was a copy. The court found that an error had occurred during the collation of the bid submission which was inadvertent and condonable. Furthermore, in light of the fact that the applicant had submitted a very competitive price, the court held that condonation would have promoted the values of fairness, competitiveness and cost effectiveness, thus advancing the public interest. The court further held that the purpose of the clearance certificate had to be kept in mind, namely
} 
application to set aside a decision taken by a municipality to allow a bidder to submit a tax clearance certificate after the closing date of the bid $^{56}$ and held that a disqualified bidder should have been afforded a hearing to explain the submission of an apparently invalid tax clearance certificate before its bid was rejected. ${ }^{57}$

\section{$32 \quad$ Strict compliance}

Minister of Environmental Affairs and Tourism and Another $v$ Pepper Bay Fishing (Pty) $L t d^{58}$ is a prime example of the strict approach. In this case, the Department of Environmental Affairs and Tourism issued a General Notice inviting the public to apply for fishing rights in terms of the Marine Living Resources Act of 1998 (South Africa). Pepper Bay (Pty) Ltd as well as a certain Mr Smith were among the applicants for fishing rights. The Chief Director rejected Pepper Bay's application on the basis that the application fee had not been paid timeously. Pepper Bay had in fact paid the required fee three days before the closing date but its accountant had mistakenly post-dated the cheque, with the result that the cheque was not honoured on the closing date. Smith's application on the other hand was rejected because it was submitted late. Smith's agent had in fact arrived timeously but the officials present refused to accept the application when it was discovered that it was not

that it serves to establish that the entities which are to be awarded municipal contracts are not in breach of their contractual and statutory obligations in respect of municipal services. The court stated that a simple telephone call to the municipality which had issued the clearance certificate would have revealed whether the bidder had cleared his municipal accounts or not.

56 Imvusa Trading 134 CC \& Another v Dr Ruth S Mompati District Municipality Case no 2628/08 (Bophutatswana Provincial Division) delivered 20 November 2008 (unreported). In this case, the successful bidder, an entity known as Mom Building and Distributors had submitted an expired tax clearance certificate (TCC) with its tender submission. This was in conflict with the bid requirements which clearly stated that failure to submit an original and valid TCC by the closing date and time of the bid would invalidate the tender. As a result, the Bid Evaluation Committee recommended the award to the applicant company and not to Mom and Co. However, the Bid Adjudication Committee (BAC) took a decision to allow Mom and Co to submit a fresh TCC and subsequently awarded the tender to it. The applicant sought to interdict the bid process on the grounds that the municipality should not have afforded Mom \& Co a further opportunity to provide a TCC. Quite remarkably, the court upheld the decision taken by the BAC to allow Mom \& Co an opportunity to provide a fresh TCC after the closing date of the tender. The court found that at all material times, the tax affairs of Mom \& Co were in order. What was lacking, said the court, was proof of this fact. The court reasoned that the BAC had simply corrected a bona fide mistake which Mom \& Co had made. The court found that the BAC was entitled to condone the omission to provide a TCC by the closing date.

${ }^{57}$ Freedom Stationery (Pty) Ltd and Another v MEC for Education, Eastern Cape [2011] JOL 26927 (E). In this case, the disqualified bidder had initially been recommended as the successful bidder to deliver text books to schools in the Eastern Cape. However, shortly before the final tender award was to be made the tender was cancelled, ostensibly because the bidder was not in possession of a valid tax clearance certificate. It later transpired that SARS had made an error in stating that there was a debit balance in respect of the bidder's account. The court held that if the bidder had been given an opportunity to explain itself regarding the validity of its tax clearance certificate it would have proved that it was indeed tax compliant - see para 27. In Azcon Projects CC v National Minister Department of Public Works, Mthatha and Another [2011] JOL 27630 (ECM), the court drew on the judgments of the Imvusa and Freedom Stationery cases and stated that an administrator is entitled to verify facts with SARS which are material to the validity or otherwise of a tax clearance certificate.

${ }^{58}$ Minister of Environmental Affairs and Tourism and Another v Pepper Bay Fishing (Pty) Ltd; Minister of Environmental Affairs and Tourism and another v Smith 2003 (4) SA 1 (SCA). The case did not deal with public procurement specifically, but rather with an application for fishing rights. 
accompanied by two copies of the original as prescribed in the General Notice. ${ }^{59}$ The agent was afforded the opportunity to return the following day with the original application and the two copies, but the application was ultimately rejected by the Chief Director on the grounds that it was received late. The SCA upheld the decision taken by the Chief Director to disqualify the applicants on the grounds that an administrative authority has no inherent power to condone failure to comply with mandatory provisions, but may only condone non-compliance if it was afforded the discretion to do so. ${ }^{60}$ Since the General Notice did not vest the Department with the discretion to condone, the court found that it had none. ${ }^{61}$

In Moroka Municipality the SCA endorsed the approach it had adopted in Pepper Bay and upheld a decision taken by a municipal entity to disqualify a bidder from a tender process on the grounds that the bidder had supplied a copy of a tax clearance certificate and not an original as required in the bid documents. The court stated that it was for the municipality and not the court to decide what the prerequisites for a valid tender ought to be. The court also reiterated that a bid which failed to comply with a stated requirement could not be regarded as an "acceptable" tender, unless the stated requirement was immaterial, unreasonable or unconstitutional. ${ }^{62}$ The court stated that had the municipality decided to accept the respondent's tender despite its shortcomings, such decision would have been invalid and liable to be set aside on the grounds that it did not qualify as an "acceptable tender". This is based on the JFE Sapela Electronics ruling.

The strict approach was also followed in Sizabonke Civils CC t/a Plascon Projects v OR Tambo District Municipality \& Others $^{63}$ in which a municipality had decided to exclude a bidder from a tender process for failure to provide a certified copy of the company's founding statement as well as certified copies of the identity documents of its directors. In upholding the decision to exclude the bidder, the court held that the municipality was not required to find out from bidders why they had not complied with a simple, essential and sufficiently highlighted provision in the bid document. ${ }^{64}$

\section{A purposive approach}

In AllPay 1, the Constitutional Court eschewed both an overly rigid as well as an overly flexible approach and instead adopted a purposive approach to the issue of bid responsiveness. In terms of

\footnotetext{
${ }^{59}$ The General Notice issued to applicants read as follows: "No applications received after 12h00, Friday 13 September 2001 will be accepted or considered. It is the applicant's responsibility to ensure that the application reaches the Rights Verification Unit/Department by the closing date. Delays by the Post Office, courier or other delivery services will not be considered a valid reason for accepting a late application." The Notice also stipulated that applicants "must submit one original application form and two copies".

${ }^{60}$ Pepper Bay, para 31.

61 Para 32. The court drew a distinction between statutes which provide for the acquisition of a right or privilege as opposed to statutes which infringe upon a right or privilege and pointed out that "when a statute provides for the acquisition of a right or privilege - as opposed to the infringement of an existing right compliance with formalities that are prescribed for such acquisition should be regarded as imperative".

${ }^{62}$ Moroka Municipality, para 10. The court stated that it was not unreasonable, unconstitutional, irrelevant or immaterial for the municipality to have required an original as opposed to a copy of a tax clearance certificate.

63 [2010] JOL 26195 (ECM).

${ }^{64}$ Para 28.
} 
this approach, the key question to ask is "whether what the applicant did constituted compliance with the statutory provisions viewed in light of their purpose" ${ }^{65}$

Thus, if the purpose of the bid requirement was achieved despite the fact that the provision was not fully complied with, the bidder should be regarded as sufficiently compliant and not be disqualified. The purposive approach is less formalistic as it focuses attention away from the classification of a requirement as "mandatory" or "permissive" and instead engages with the more fundamental question as to whether the bid requirement in question is material (whether it serves an important purpose) and whether that purpose was in fact achieved, despite the imperfect compliance.

The purposive approach is by no means new to our law. ${ }^{66}$ Indeed, this approach had been adopted by the Constitutional Court in the earlier case of $A C D P .{ }^{67}$ Also, as already mentioned, in the case of Millennium Waste the SCA held that a bidder who completed a declaration of interest form, but failed to sign it should not have been disqualified since the purpose of the bid requirement (i.e. the full declaration of interest) was met, despite the imperfect compliance. ${ }^{68}$ There may thus be instances where substantial compliance with the tender terms and conditions (as opposed to perfect compliance), would suffice.

One of the grounds of complaint raised by the unsuccessful bidder in the AllPay cases was that the successful bidder, Cash Paymaster (Pty) Ltd, had failed to comply with a mandatory requirement of the RFP, namely the requirement to prepare separate bids for each of the provinces for which it intended to submit RFP responses. (Cash Paymaster had simply submitted one bid in respect of all nine provinces and not separate bids as stated). Following a purposive approach, the court found that there had been sufficient compliance with the bid requirement, despite the fact that Cash Paymasters had not complied in the precise manner prescribed in the tender document. The basis

\footnotetext{
${ }^{65}$ Allpay 1, para 30. The Constitutional Court relied on its earlier decision in ACDP v Electoral Commission 2006 (3) SA 305 (CC).

${ }^{66}$ Hoexter 2012: 263, Maharaj v Rampersad 1964 (4) SA 638 (A).

${ }^{67}$ In this case, the Electoral Commission (the Commission) had disqualified the African Christian Democratic Party (ACDP) from participating in local government elections for the Cape Town Metro for failure to pay a deposit by way of a bank guaranteed cheque on or before a stipulated date, as require by ss 14 and 17 of the Local Government: Municipal Electoral Act of 2000 (South Africa). The ACDP had submitted both its party list as well as its nominated ward candidates timeously. It had also made a bulk payment of R283 000,00 by way of a bank guaranteed cheque in respect of a number of municipalities indicated on a list in which it intended to contest elections. However, due to an error on its part, the Cape Town Metro was not included on the list. The ACDP later decided not to contest elections in certain wards in respect of which it had made the bulk deposit, with the result that the commission held a credit balance of R10 000 in favour of the ACDP. The ACDP took the view that the surplus of funds in the account of the ACDP could be allocated as a deposit for the Cape Town Metro. However, the commission held the view that the provisions of the Act were peremptory and that it did not have the power to condone non-compliance. The Constitutional Court held that the surplus of funds held by the commission constituted sufficient compliance with the Act. The court placed great emphasis on the importance of promoting multi-party democracy and the right of citizens to vote. The court furthermore held that the payment of a deposit was not a key purpose of ss 14 and 17 of the Act. The underlying purpose of the Act, said the court, was to ensure that candidates and political parties wishing to contest elections should declare their intention to do so by a particular date and time and to provide the commission with the necessary information to organise the elections. The payment of the deposit was complementary to the notification of the intention to participate in elections and to furnish details of candidates. The court also held that no other party or candidate would be harmed by a more generous interpretation of the Act.

${ }^{68}$ At 8 above.
} 
for this finding was that the purpose of the requirement had been met, despite the imperfect compliance. The court reasoned that:

"[T]he purpose of separate bids for the provinces was surely to enable [the South African Social Security Agency (SASSA)] to assess whether the bidder would be able to provide the necessary services in each of the provinces for which it bid. This purpose was attained" ${ }^{69}$

Not only is it important to enquire into whether the purpose of the bid requirement was achieved, it is also important to enquire into whether the bid requirement itself is material i.e. whether it serves an essential purpose. In terms of the PAJA, an organ of state may be taken on review if "a mandatory and material procedure or condition prescribed by an empowering provision was not complied with". ${ }^{70}$

Thus, to trigger a successful review application based on non-compliance with bid requirements, it must be established that the provision in question is both mandatory and material. As a general principle, non-compliance with a requirement which has been categorised in the bid document as mandatory but which does not serve a material purpose should not be regarded as a fatal irregularity. For example, non-compliance with a mandatory requirement that bidders are required to complete their bid submissions in black ink, would not necessarily result in disqualification, if the organ of state cannot establish that such a requirement served an essential or material purpose.

The particular wording of the RFP document will play an important role in determining the materiality and purpose of a bid requirement. However, this does not mean that courts are to draw on the discredited distinction between "mandatory" and "directory" provisions. ${ }^{71}$ In AllPay 1, the unsuccessful bidder alleged that the organ of state concerned failed to comply with a requirement outlined in its internal circulars, namely, that a Bid Evaluation Committee (BEC) had to consist of at least five officials, one of whom should be a supply chain management practitioner. (The BEC consisted of four officials, none of whom was a supply chain practitioner). However, the Constitutional Court pointed out that the internal circular stated that a supply chain practitioner "should" be appointed - as opposed to "must" be appointed. Given the non-mandatory nature of the term "should", the court found that there was no basis for the argument that there had been non-compliance with a mandatory and material requirement.

\section{Condonation}

In Moroka Municipality, the SCA revisited its earlier stance in Millennium Waste on the power of administrative bodies to condone non-compliance with bid requirements. As stated above, Moroka Municipality made it clear that administrative bodies only have powers to condone non-compliance to the extent that they have been given such powers in the bid documents or other enabling

\footnotetext{
${ }^{69}$ Allpay 1, para 64.

70 PAJA s 6(2)(b) (own emphasis).

${ }^{71}$ Our law used to draw a formal distinction between "mandatory" and "directory" provisions. Mandatory provisions use terms such as "shall" or "must" and required strict compliance, whereas directory language employ permissive language and required only substantial compliance or even non-compliance (AllPay 1, para 30, Hoexter 2012: 49). However, the terms "mandatory" and "directory" have been described as an "uncertain guide" (Hoexter 2012: 292) and have since been discarded from our law (AllPay 1, para 30).
} 
provisions, or unless the bid requirement itself is immaterial, unreasonable or unconstitutional. Moroka Municipality also overruled Millennium Waste to the extent that the latter judgment indicated that administrative bodies have power to condone non-compliance when the public interest would be advanced by such condonation. The correct position as explained by the SCA is that a benefit may be waived by an individual or body provided that no public interests were affected by the waiver. ${ }^{72}$ The court stated that to allow administrative bodies to condone noncompliance with mandatory provisions in the "public interest" may also offend the principle of legality. ${ }^{73}$

The clarification provided by Moroka Municipality on the issue of condonation in the "public interest" is to be welcomed. The notion espoused by the SCA in Millennium Waste, was simply too imprecise to serve as a reliable guide for administrators. It must be borne in mind that most administrators are not trained legal professionals and yet are often required to make decisions which have profound legal consequences. For this reason, administrators require a clear and logical framework for decision making to guide the exercise of their discretion. This is not to suggest that the judiciary should write policy directives for administrators. However, when the courts establish novel principles which affect the administration, administrators could be forgiven for expecting some level of clarity on the criteria which are to be considered when their powers are to be exercised. Millennium Waste conjured up the rather bewildering prospect that non-compliant bidders who provided competitive pricing could have their non-compliance condoned "in the public interest" and thus allowed to participate in the bidding process, whereas other non-compliant bidders whose pricing was less competitive could be disqualified. Such an approach lends itself to arbitrary and discriminatory treatment and serves as fertile ground for litigation.

More recently, the concept of "public interest" has been used as a reason not to condone noncompliance with bid requirements. In AllPay 1, the court stated that the public has a compelling interest in requiring uniform observance of bid requirements. ${ }^{74}$ This theme was repeated in AllPay 2, in which the Constitutional Court invoked the public interest to justify declaring a bid invalid which had not complied with tender requirements. Our jurisprudence now dictates that whilst the concept of public interest is paramount in procurement matters, it is not one dimensional and can in fact be used to justify the exclusion of non-compliant bids. ${ }^{75}$

However, the decision in Moroka Municipality has created its own anomalies. By insisting that administrators have no authority to condone non-compliance if they have not specifically been given the discretion to do so, the judgment could be interpreted as a retreat into formalism. The court's reliance on the Pepper Bay judgment as an authoritative exposition on the current state of the law is also open to doubt. It will be recalled that in the Pepper Bay case, the court upheld a decision taken by the Chief Director to reject an application for fishing rights on the grounds that it was delivered

\footnotetext{
${ }^{72}$ Moroka Municipality, para 18. This is based on the common law maxim quilibet potest runtiare juri pro se introducto - no man may renounce a right which his duty to the public and which the claims of society forbids the renunciation of. Thus, for example, a statutory requirement that a claim for damages must be instituted against a local authority within a prescribed time period, may be waived by that local authority, as such requirement exists purely for the benefit of the local authority.

${ }^{73}$ Moroka Municipality, para 18.

${ }^{74}$ Allpay 1, para 24.

${ }^{75}$ Allpay 2, para 33.
} 
late. ${ }^{76}$ The real reason however why the application was rejected when it was initially presented was that it was not accompanied by two copies of the original. For the following reasons, it is submitted that the approach adopted in Pepper Bay has been eclipsed by the more recent AllPay rulings. Firstly, the strict formalism adopted in Pepper Bay is at odds with the purposive approach adopted in AllPay $1 .{ }^{77}$ In light of AllPay 1 , the focus has shifted - the fundamental issue is no longer whether administrators were given the discretion to condone non-compliance with bid requirements, but rather whether the purpose of the requirement was achieved and indeed whether the bid requirement itself is material. This is not to suggest that the wording of the empowering provision is irrelevant or that due weight ought no longer to be given to the peremptory nature of the language used. However, the difficulty with Pepper Bay is that it regarded the peremptory terms of the General Notice, coupled with the absence of a discretion, as dispositive of the question as to how non-compliance ought to be dealt with. AllPay 1 on the other hand vindicates the view that courts ought to adopt a broader perspective on the legal consequences of non-compliance.

Secondly, it must be borne in mind that Pepper Bay was decided at a time when our courts placed great emphasis on the distinction between so called "peremptory" and "directory" provisions. ${ }^{78}$ In terms of this approach, peremptory provisions required strict compliance whereas directory provisions did not. ${ }^{79}$ As indicated above,${ }^{80}$ this distinction has been criticised as an "uncertain guide" and has since been jettisoned from our law. ${ }^{81}$ Today, the evaluation of compliance with legal requirements is "an exercise unencumbered by excessive formality" ${ }^{82}$

Thirdly, it could be argued that the requirement that the original application be accompanied by two copies did not serve an "essential" or "material" purpose in the decision making process. What was material was that the original application had to be submitted by a particular date and time. The additional copies would not have served any significant purpose and in all probability this requirement was included purely for the convenience of the administrators. The essential purpose of the General Notice was to inform all applicants who wished to have their applications for fishing rights considered that they had to ensure that their application reached the department before a particular cut off period. Arguably, Mr Smith satisfied this purpose by submitting his original application on time, despite the fact that it was not accompanied by two copies. Had due consideration been given to the materiality of the requirement (as now required in the light of AllPay 1) the outcome of the matter may have been different. ${ }^{83}$

\footnotetext{
${ }^{76}$ See 10 above for a summary of the facts in Pepper Bay.

77 The strict application of the requirement of an original tax clearance certificate may have been justified because the standard form tax clearance certificate issued by SARS contains a standard disclaimer that copies of the original are not regarded as valid. However, the basis of the court's reasoning (i.e. that organs of state have no discretion to condone non-compliance unless specifically authorised to do so) appears to be out of step with the recent jurisprudence emanating from the Constitutional Court in AllPay 1.

${ }^{78}$ See Pepper Bay judgment, para 32.

${ }^{79}$ See AllPay 1, para 30.

${ }^{80} \mathrm{~N} 71$ (Hoexter 2012: 292).

${ }^{81}$ AllPay 1, para 30.

${ }^{82}$ Para 30.

${ }^{83}$ In the court a quo, Davis J remarked that: "[T]he idea that an official should be entitled to reject an application which was properly completed and where payment was timeously lodged so that the only difficulty with the entire application concerned copies delivered a day late offends an elementary application of the value of justice". See Smith v Minister of Environmental Affairs \& Tourism 2003 (1) SA 628 (C) 636.
} 
Fourthly, subsequent to the Pepper Bay judgment, the SCA accepted that fairness sometimes requires that bidders be allowed an opportunity to rectify an innocent mistake. ${ }^{84}$ The rejection of bids based on immaterial and innocent mistakes undermines the constitutional objectives of cost effectiveness and competitiveness in public procurement. The post-dating of the cheque by Pepper Bay (Pty) Ltd's accountant, which resulted in the payment not being cleared on the closing date of the bids, could surely have been regarded as an "innocent mistake". As stated above, in the matter of ACDP v Independent Electoral Commission, a failure to pay a deposit by a particular date and time was held not to constitute a fatal irregularity. In AllPay 1 , the line of reasoning adopted in ACDP was applied within the procurement context. Had this reasoning been applied in Pepper Bay, the court may well have concluded that the payment of the deposit was complementary to the primary objective of ensuring that all applicants who wished to have their applications for fishing rights considered, were required to submit their applications timeously. The court may also have concluded that no other applicant would have been prejudiced by this approach.

Our case law reveals other (somewhat extreme) examples of where formalism was allowed to triumph over common sense. In VE Reticulation (Pty) Ltd and Others v Mossel Bay Municipality and Others ${ }^{85}$ the court upheld a decision taken by a municipality to disqualify a bidder who had failed to provide a so called ECB certificate (ie. a certificate issued by the Electrical Contracting Board [ECB]) even though an ECB certificate was strictly speaking irrelevant for purposes of the services that were put out to tender and was erroneously included in the tender. ${ }^{86}$ Also, the case of Basadi JV \& Others $\checkmark$ MEC of Education, Province of the Free State \&Others ${ }^{87}$ illustrates that reasonable (and indeed necessary) bid conditions may sometimes be applied in an unreasonable manner, if the peculiar circumstances of the non-compliant bidder as well as the reasons for its non-compliance are not properly considered. In this instance the court upheld a decision taken by an administrative body to disqualify an unincorporated joint venture for failing to provide a valid tax clearance certificate, even though the unincorporated joint venture was not legally required to provide a tax clearance certificate. $^{88}$ Moreover, both companies which formed the joint venture had submitted valid

\footnotetext{
${ }^{84}$ Metro Projects CC v Klerksdorp Local Municipality 2004 (1) SA 16 (SCA) para 13.

${ }^{85} 2013$ (2) SA 489 (WCC).

${ }^{86}$ An ECB certificate is required for household electrical installations and not bulk electrical infrastructure as was stipulated in the tender. The court held that if the applicants believed that the requirement was irrelevant they should have cleared the position with the municipality prior to submitting their bid, but could not cry foul when they participated in the tender with full knowledge of the tender specifications, but failed to adhere to them. The court furthermore held that the failure to submit the certificate was not due to an obvious mistake on the part of the applicant, as it had taken a view that the certificate was unnecessary and irrelevant and for that reason did not submit it. The failure to provide the certificate was therefore the result of a deliberate decision. The court also held that to have disregarded the requirement to produce an ECB certificate would have been unfair to other bidders who would have submitted tenders but did not do so because they did not have such a certificate. Consequently, the court ruled that there was no duty on the municipality to have afforded the applicants an opportunity to rectify the situation by providing the certificate.

${ }^{87}$ [2008] JOL 21070 (O).

${ }^{88}$ Regulation 14 of the Preferential Procurement Regulations of 2011 (GNR.502/GG 34350), promulgated in terms of the PPPFA, reads: "No tender may be awarded to any person whose tax matters have not been declared by the South African Revenue Service to be in order" (own emphasis). The obligation to provide proof of tax compliance thus only applies to a "person". A "person" is defined in law as either a natural or a juristic person. Consequently, the obligation to provide a tax clearance certificate does not apply to entities which are not considered to be "persons", such as unincorporated joint ventures.
} 
certificates. $^{89}$

The approach of the courts in these instances illustrate the dangers of elevating immaterial, irrational and unreasonable bid requirements to a level where they are allowed to determine the fate of the bid. As such they are at odds with the principles outlined in Allpay 1 and ought not to be regarded as authoritative.

\section{Conclusion}

One of the key ingredients of the notion of fairness in public procurement is that bidders must be treated fairly in relation to each other. ${ }^{90}$ This means that no bidder should be afforded preferential treatment that he or she was not legally entitled to. The judgment of the Constitutional Court in Allpay 1 vindicates the principle that observance of bid requirements by all bidders in a tender process is fundamentally important in that it promotes equal treatment of bidders. For that reason, bidders as well as procuring authorities may not disregard bid requirements at whim.

However, this principle should not be applied in an unreflective and mechanical fashion. Administrators should guard against disqualifying non-compliant bidders irrespective of the degree of materiality of the bid requirement. As stated in $A C D P$, "a narrowly textual and legalistic approach is to be avoided". ${ }^{91}$

Consequently, not all bid requirements should be applied with the same degree of strictness and not every instance of non-compliance with bid requirements should automatically result in bid invalidity. In the Metro Projects case, the SCA recognised that there are degrees of compliance with any standard "and it is notoriously difficult to assess whether less than perfect compliance falls on one side or the other of the validity divide".$^{92}$

A process of fair-minded reasoning requires that bids be assessed on their merits and not be excluded for relatively minor breaches. Such an approach gives effect to the values of fairness, equity, transparency, competitiveness and cost effectiveness enshrined in section 217(1) of the Constitution. Thus, the courts are required to enquire into the underlying objective and materiality of a bid requirement, to ascertain whether its purpose was in fact met despite less than perfect compliance. A decision whether or not to exclude a non-compliant bidder from a bid process will depend on a variety of factors including: the wording of the RFP, the materiality of the unfulfilled requirements, the degree of non-compliance and the purpose of the requirement.

\footnotetext{
${ }^{89}$ The court reasoned (at 5 ) that the unincorporated joint venture only had itself to blame for its exclusion by (erroneously) submitting a VAT registration number with its bid, thus bringing the tender committee under the impression that it was registered for tax purposes.

${ }^{90}$ Bolton 2007: 48 \& 181.

${ }^{91}$ ACDP, para 25. See also Moseme Road Construction CC v King Civil Engineering Contractors (Pty) Ltd 2010 (3) SA 549 (SCA) in which the court cautioned that not every slip in the administration of tenders should be regarded as fatal (para 21).

${ }_{92}$ Metro Projects, para 15. See also Stellenbosch Municipality \& Another v Fusion Properties 233 CC \& Others [2009] JOL 24603 (WCC) in which the court stated (para 76) that there is no exact measure or yardstick for what is fair, as fairness ultimately involves a value judgment: "As long as the overall purpose of the Act is met, substantial compliance with its requirements suffices."
} 
Finally, it is not sufficient to simply invoke the familiar incantation that "substance must be placed over form". This mantra is singularly unhelpful if not accompanied by clear guidelines to assist administrators when exercising their powers. The text box below, outlines some of the factors which should be taken into account when considering the consequence of non-compliance with bid requirements. It must however be emphasised that this is not a checklist but rather a framework for decision making in which certain factors may gain prominence over others, depending on the peculiar circumstances of each matter.

Framework for determining the consequences of non-compliance with bid requirements

- Does the language of the RFP indicate that compliance with the requirement is mandatory?

- Is the requirement stated in a clear and unambiguous manner?

- Were the consequences of non-compliance clearly spelt out in the bid document and/or the tender briefing session?

- Has the requirement been introduced solely for the benefit or convenience of the organ of state concerned?

- Is the requirement rational in relation to the reasons given for its inclusion?

- Does the requirement serve a legitimate and essential purpose having regard to the tender as a whole?

- Is the inclusion of the requirement sanctioned by legislation or the procurement policy of the organ of state?

- Have procurement officials been vested with a discretion to condone non-compliance?

- What explanation, if any, was provided by the non-compliant bidder for his/her non responsiveness?

- What is the degree of the non-compliance? Has there been substantial compliance with the requirement?

- Has the purpose of the bid requirement been met, despite the imperfect compliance?

- Would it be unfair to other bidders if the non-compliant bidder were to be afforded an opportunity to rectify the non-compliance? Would affording such an opportunity to the noncompliant bidder effectively allow him or her to improve the merits of their bid? 


\section{Bibliography}

$\underline{\text { Books }}$

Bolton, P. 2007. The Law of Government Procurement in South Africa. Durban: Lexis Nexis.

Hoexter, C. 2012. Administrative Law in South Africa. Claremont: Juta Publishers.

\section{Case Law}

ACDP v Electoral Commission 2006 (3) SA 305 (CC).

AllPay Consolidated Investment Holdings (Pty) Ltd and Others v Chief Executive Officer of the South African Social Security Agency and Others [2013] 2 All SA 501 (SCA).

AllPay Consolidated Investment Holdings (Pty) Ltd and others v Chief Executive Officer of the South African Social Security Agency and Others 2014 (1) BCLR 1 (CC).

AllPay Consolidated Investment Holdings (Pty) Ltd v Chief Executive SASSA (No 2) 2014 (6) BCLR 641 (CC).

Azcon Projects CC v National Minister Department of Public Works, Mthatha and Another [2011] JOL 27630 (ECM).

Basadi JV v MEC for Education, Province of the Free State [2008] JOL 21070 (0).

Bato Star Fishing (Pty) Ltd v Minister of Environmental Affairs 2004 (4) SA 490 (CC).

Chairperson: Standing Tender Committee and Others v JFE Sapela Electronics (Pty) Itd and Others [2005] 4 All SA 487 (SCA).

Dr J S Moroka Municipality v Betram (Pty) Ltd [2014] 1 All SA 545 (SCA).

Freedom Stationery (Pty) Ltd and Another v MEC for Education, Eastern Cape [2011] JOL 26927 (E).

GVK Siyazama Building Contractors (Pty) Ltd v Minister of Public Works [2007] JOL 20439(D).

Imvusa Trading 134 CC \& another v Dr Ruth S Mompati District Municipality \& 4 others, case 2628/08

(Bophuthatswana Provincial Division) dated 20 November 2008.

Johannesburg Stock Exchange v Witwatersrand Nigel Ltd and another [1998] 2 All SA 308 (A).

Logbro Properties CC v Bedderson NO \& Another 2003 (2) SA 460 (SCA).

Maharaj v Rampersad 1964 (4) SA 638 (A).

Metro Projects CC v Klerksdorp Local Municipality 2004 (1) SA 16 (SCA).

Millennium Waste Management (Pty) Ltd v Chairperson Tender Board: Limpopo Province [2008] 2 All SA 145 (SCA).

Minister of Environmental Affairs and Tourism v Pepper Bay Fishing (Pty) Ltd; Minister of Environmental Affairs and Tourism v Smith [2003] 4 All SA 1 (SCA).

Minister of Social Development v Phoenix Cash and Carry 2007 (9) BCLR 982 (SCA).

Sizabonke Civils CC t/a Plascon Projects v OR Tambo Distrct Municipality [2010] JOL 26195 (ECM). 
Smith v Minister of Environmental Affairs \& Tourism [2003] 1 All SA 628 (C).

Steenkamp NO v Provincial Tender Board, Eastern Cape 2007 (3) SA 121 (CC).

Stellenbosch Municipality \& Another v Fusion Properties 233 CC \& Others [2009] JOL 24603 (WCC).

Tedcor (Pty) Ltd v Mbombela Local Municipality and another [2006] JOL 17762 (T).

VDZ Construction (Pty) Ltd v Makana Municipality \& Others [2011] JOL 28061 (ECG).

VE Reticulation (Pty) Ltd v Mossel Bay Municipality [2013] 2 All SA 489 (WCC).

Xantium Trading 42 (Pty) Ltd v South African Diamond and Precious Metals Regulator and another [2013] JOL 30148 (GSJ).

$\underline{\text { Legislation }}$

\section{Acts of Parliament}

Broad-Based Black Economic Empowerment Act of 2003 (South Africa)

Constitution of the Republic of South Africa, 1996.

Limpopo Tender Board Act of 1994 (South Africa)

Local Government: Municipal Electoral Act of 2000 (South Africa)

Marine Living Resources Act of 1998 (South Africa)

Preferential Procurement Policy Framework Act of 2000 (South Africa)

Promotion of Administrative Justice Act of 2000 (South Africa)

Public Finance Management Act of 1999 (South Africa)

$\underline{\text { Regulations }}$

Preferential Procurement Regulations of 2011 (GNR.502/GG 34350)

Regulations in terms of the Limpopo Tender Board Act 2 of 1994 PN 4/1997

Other sources

GN 691/1997 Green Paper on Public Sector Reform Procurement Reform in South Africa (April 1997).

UNCITRAL Model Law on Public Procurement A/66/17 of 1 July 2011. 